\title{
Remote Access Unit for Optic-to-Wireless Conversion
}

Chorchos, ukasz; Rommel, Simon; Turkiewicz, J. P.; Tafur Monroy, Idelfonso ; Vegas Olmos, Juan José

Link to article, DOI:

10.1109/PIERS.2016.7734974

Publication date:

2016

Document Version

Publisher's PDF, also known as Version of record

Link back to DTU Orbit

Citation (APA):

Chorchos, ., Rommel, S., Turkiewicz, J. P., Tafur Monroy, I., \& Vegas Olmos, J. J. (2016). Remote Access Unit for Optic-to-Wireless Conversion. Abstract from Progress In Electromagnetics Research Symposium 2016, Shanghai, China. https://doi.org/10.1109/PIERS.2016.7734974

\section{General rights}

Copyright and moral rights for the publications made accessible in the public portal are retained by the authors and/or other copyright owners and it is a condition of accessing publications that users recognise and abide by the legal requirements associated with these rights.

- Users may download and print one copy of any publication from the public portal for the purpose of private study or research.

- You may not further distribute the material or use it for any profit-making activity or commercial gain

- You may freely distribute the URL identifying the publication in the public portal

If you believe that this document breaches copyright please contact us providing details, and we will remove access to the work immediately and investigate your claim. 


\title{
Remote Access Unit for Optic-to-Wireless Conversion
}

\author{
L. Chorchos ${ }^{1}$, S. Rommel ${ }^{2}$, J. P. Turkiewicz ${ }^{1}$, I. T. Monroy², J.J. Vegas Olmos ${ }^{2}$ \\ ${ }^{1}$ Institute of Telecommunications \\ Warsaw University of Technology \\ 00-665 Warsaw, Poland
${ }^{2}$ Department of Photonics Engineering, Technical University of Denmark 2800 Kgs. Lyngby, Denmark

\begin{abstract}
In this paper we propose a design of a reconfigurable Remote Access Unit (RAU) interfacing optical dense wavelength division multiplexed (DWDM) networks with radio communication links. To generate a radio signal the device utilizes a principles of incoherent heterodyne signal upconversion. The proposed RAU is able to operate in a whole optical C-band with $100 \mathrm{GHz}$ spaced channels and can generate radio signals in a wide frequency range limited only by used photodiode. Experimental tests of the RAU showed error free operation after $15 \mathrm{~km}$ of fiber and $50 \mathrm{~m}$ of radio link in $\mathrm{W}$-band frequency range.
\end{abstract}

Growing demand for high speed wireless data transmission and new wireless standards like 5G force network operators to find new solutions for backhaul networks. Presently, to meet this need, attention of many researchers and top network vendors has been directed towards millimeter wave radio links. Operation in the millimeter wave range brings new possibilities for a channel allocation as well as allows wider radio channels to be used. Moreover this frequency range is lighter licensed than regular GSM. This clearly shows a huge potential of millimeter waves for a high speed wireless data transmission. Nevertheless operation in the millimeter wave range struggles with one problem - traditional generation of signals in this frequency range is complex. To overcome this issue and provide simple integration of radio networks with present and future optical networks use of optical heterodyne signal upconversion was proposed and research projects like IPHOBAC-NG were founded. The aim of the mentioned project is to employ novel RAUs featuring opticto-wireless and wireless-to-optic conversion with a speeds of 1-10Gbit/s for broadband wireless access and up to 3Gbit/s for mobile backhaul. The RAU proposed in this paper is in line with these assumptions.

The principle of operation of the proposed RAU is as follow: when DWDM signal enters RAU a desired data channel is selected with a widely tunable fiber Fabry-Perot optical filter. Next signal is combined with a reference signal from a local oscillator spaced accordingly to the chosen radio frequency. Both signals are fed into a photodiode with $90 \mathrm{GHz}$ bandwidth and transmitted with antenas. The local oscillator and tunable filter are controlled over processing unit that can be easily connected to the management network. The filter and local oscillator are widely tunable what brings broad range of possible configurations. Tests in real-likely conditions showed great RAU's performance and allowed wireless transmission with the bit error rate at the level of $1^{-10}$.

\section{ACKNOWLEDGMENT}

This work was partly funded by the DFF FTP mmW-SPRAWL and EC IPHOBAC-NG projects. 